\title{
“Are We Having Fun Yet?” What Factors Influence Managers to Have Fun at Work?
}

\section{Scardillo A*}

Department of Business and Management, Mount Saint Mary College, 330 Powell Avenue, Newburgh, NY, USA

\begin{abstract}
Contrary to the popular saying, managers are NOT having fun at work. In fact, nearly $70 \%$ of all employees are dissatisfied with their jobs. The reasons are many, and have been written about in numerous articles, but the underlying reason is that they are not having any fun!

We believe that a fun and engaging workplace impacts employee engagement, morale, productivity and safety. We also believe that creating a fun atmosphere at work is accomplished only when management is having fun. The thinking is that if management is having fun at work, then employees will have more fun in a give-and-take feedback loop. We discovered six important factors that influenced managers to have fun at work. Among them were Mentoring, New Challenges, Empowerment, Peer/Co-Worker Relationships, Meaningful Work and Fun Activities (in order of importance). This qualitative study examines these factors and the significance of their influence on managers to have fun at work.
\end{abstract}

Keywords: Fun; Mentor; Protege; Hard Work; Meaningful Work; Autonomy

\section{Introduction}

For the first 25 years of my professional career, I had fun at work. I enjoyed every facet of my work, especially the challenges it brought. I looked forward to each day, and felt great satisfaction when the challenges were not only accomplished, but surpassed [1-3]. That all changed in 2003 when I left my comfortable job in sales, marketing and corporate communications for two "dead-end" jobs [4,5], ones that had no redeeming value, just a paycheck. Worse yet, they were "cesspools" - environments that were toxic and un-motivating [69]. I now know what it was like to not have fun at work. There are numerous causes, but a great deal of literature identifies the high expectations placed on management to produce profits as the primary reason [10]. Those expectations, and the stress they create, make managers more demanding and less forgiving [10], and leads to an unhealthy relationship between manager and employee [6]. This rift makes employees less willing to contribute and reduces productivity [11-13] creates an unsafe workplace [14], and leads to a lack of personal esteem [15]. This type of management can be paralyzing in the long-term [6]. My theory is that if the manager is having fun at work, then the employees will have fun, too [6]. This study is focused on understanding what factors influence management to have fun at work. This qualitative study will employ a grounded-theory utilizing semi-structured interviews of managers and employees from small to mid-sized companies.

\section{Research Question}

What Factors Influence Managers to Have Fun at Work?

\section{Literature Review}

In keeping with the spirit of the Grounded-Theory approach, this section was written after the study, data collection and analysis were completed. It appears in the Discussion section. Author Robert Ford writes that fun has received a great deal of attention, yet there is a great gap in the literature regarding the benefits - and consequences - of having fun at work [2]. Their research specifically looked at fun through the eyes of Human Resource Managers, the individuals responsible in many companies for implementing such programs. The HR Managers typically evaluate various programs to determine what is most effective in promoting a fun work environment. Their findings concluded a fun environment "encourages, initiates, and supports a variety of enjoyable and pleasurable activities that positively impact the attitude and productivity of individuals and groups" [2]. The factors used to create this environment varied, but provided the employees with a sense of positive well-being, and moved them beyond the "satisfied" With their job stage to "having fun" stage [2].

Bolton's et al. work suggests that fun at work provides employees with an enhanced quality of work-life, reputation, performance, communication and group cohesiveness [8]. They note that fun is the extent to which a person perceives the existence of fun in their workplace, and that a fun environment demonstrates a higher level of caring and gives a company a competitive advantage over other, less fun firms in regards to recruiting personnel [8].

Kinjerski and Skrypnek's research discovered that leadership was the most important factor in creating a fun and spirited work environment [3]. They identified such influencers as "the ability to realize one's full potential; being associated with a good or ethical organization; interesting work; having good colleagues; serving mankind; service to future generations, and service to one's immediate community" That boosted employee's spirits at work.

\section{Methodology}

A qualitative, grounded theory approach, as formulated by Corbin and Strauss, was used to conduct this research. Grounded theory is an integrative methodology in which new theory is constructed from

*Corresponding author: Scardillo A, Department of Business and Management Mount Saint Mary College, 330 Powell Avenue, Newburgh, NY 12550, USA, Tel: 5185262520; E-mail: anthony.scardillo@msmc.edu

Recieved November 15, 2017; Accepted April 05, 2018; Published April 13, 2018

Citation: Scardillo A (2018) "Are We Having Fun Yet?" What Factors Influence Managers to Have Fun at Work?. J Entrepren Organiz Manag 7: 230. doi: 10.4172/2169-026X.1000230

Copyright: (c) 2018 Scardillo A. This is an open-access article distributed under the terms of the Creative Commons Attribution License, which permits unrestricted use, distribution, and reproduction in any medium, provided the original author and source are credited. 
"the past and present involvements and interactions with people, perspectives and research practices"

Utilizing a qualitative method in the form of semi-structured interviews and a narrative approach enables the researchers to understand what factors lead to a fun and engaging workplace. Crossley suggested that narrative research is concerned with identity, and is appropriate when understanding the experiences of employees and sensitive information.

Data was gathered through face-to-face interviews using openended questions that created context and directed the dialog. This made for a more flexible interview process with participants feeling comfortable with their responses. The interviews were designed to extract the significant factors that created a fun and engaging workplace - and those factors that created a not-so-much fun environment.

The sample used for the data collection included managers and employees in the advertising, marketing and sales industry in the Greater Albany-Schenectady-Troy, NY (Capital Region) market. One of the underlying reasons this industry was chosen was because of its naturally creative, independent and innovative approach to conducting business. The results obtained can be applied across multiple other industries and organizations and is not impacted by size or locale.

The cyclical process of conducting the interviews, reviewing the transcripts, listening to the recordings, gathering the data and coding the responses provided theoretical ideas, and themes that were broken down into categories (Table 1).

\section{Sample}

The sample included twenty-four (24) interviewees from different companies or organizations. The group was solicited through The Albany, NY Chapter of the American Marketing Association; The Albany, NY Ad Club (member of AAAA); the Albany, NY Chapter of the Public Relations Society of America (PRSA), the Capital Region Chamber of Commerce and through personal/professional contacts. The breakout is below (Table 1).

The interviews averaged one-hour in length and were conducted in "neutral" settings such as coffee shops, public libraries or third-party offices that provided the participants with a setting that allowed them to share their most intimate and personal thoughts without the fear of intrusions. IRB protocol was followed in each interview to assure consent, accuracy and confidentiality. After conducting twenty-two interviews, the researcher determined that no new themes or ideas were emerging and completed the study after the two remaining/previously scheduled interviews were concluded.

The interviews were coded using an open-coding approach made popular by Saldana. The interviews were manually, as well as electronically, coded using a custom-designed database created by the author. This allowed for a high degree of flexibility with regard to sorting and analyzing the data. After the completion of the initial coding, each interview was reviewed for consistent coding. Focused-coding and axial-coding were then applied to examine common themes. The interviews were categorized into two primary groups: FUN and NOT

\begin{tabular}{|l|c|c|c|}
\hline & Under 50 & Over 50 & Total \\
\hline M/F Level Managers & 3 & 8 & 11 \\
\hline M/F Employees & 9 & 4 & 13 \\
\hline
\end{tabular}

Table 1: Capital region chamber of commerce and through personal/professional contacts.
FUN and then further broken down into their respective demographics including age, manager or employee.

\section{Findings}

This section pertains to the data discovered through the interview process.

Early on in the interview process, it became clear that FUN and NOT FUN were two very distinctly separate categories, and provided the initial factor in developing our categories. Each response was coded as "FUN" or "NOT FUN", and then broken down into more specific/related codes. Once coded, the responses were categorized into findings, with six specific categories of Fun emerging from the data.

Overall, the respondents thought that Mentoring, Empowerment (Autonomy) and New Challenges (Hard Work) were all fun. Respondents thought that Fun Activities were fun, but with much less importance than the others. The findings are as follows (in order):

1. Mentor $91 \%$ of Respondents spoke of Mentoring as FUN

2. New Challenges $9 \%$ of all Respondents regarded New Challenges as FUN

3. Empowerment $84 \%$ of the Respondents had FUN when they were Empowered

4. Peer/Co-Worker Relationships $82 \%$ of Respondents considered strong Relationships as FUN

5. Meaningful Work $73 \%$ of Respondents had FUN when performing Meaningful Work

6. Fun Activities $70 \%$ of all Respondents had FUN through Fun Activities.

Responses that were coded as "FUN" varied across the findings, but generally consisted of statements such as:

- (Employee) Mentor: "He was open to comments from us, open to figuring out ways to do things. We gelled - it was a really great sales team. I left there in 1993, we're still in touch"

- (Employee) New Challenges: "I had fun learning how TV shows were put together. How all of that worked, how the technology worked and how there were producers and all of these people all the behind the scenes stuff. So that was fun for me to learn it and to feel like I was a part of it"

- (Manager) Empowerment: "Empowerment is giving people the capacity to say, 'What if we tried it this way?' It's, giving them ownership. Empowerment's about giving people a sense that they own their little piece of the company. And it's much more fulfilling for them, if they have that sense of ownership, and mission"

- (Employee) Peer/Co-Worker Relationships: "I liked interaction with people. I liked the team I worked with. I think that was a big important part of it. They knew how to have the appropriate fun in the workplace"

- (Employee) Meaningful Work: "I was highly motivated, and my motivating factor wasn't money. I just wanted to do a good job"

- (Manager) Fun Activities: "I was constantly manufacturing things so that people could have fun"

Below are the finds of the specific categories. 


\section{Finding: Mentor}

A great deal has been studied about "Mentorees" - the Proteges - yet Mentoring has received very little review. This is surprising since $91 \%$ of the participants made multiple references to Mentoring being fun. Of the two groups, $100 \%$ of all Managers believed that being a Mentor was fun, and $76 \%$ of all Employees felt that having a Mentor was fun. Many of our respondents used terms like "great pride", "selflessness", "joy of training", and "role model" to characterize mentoring.

\section{Management}

- "I can't tell you how many people point to me and say 'You changed my life"”

- "Since my very first opportunity to be a supervisor, I wanted to know what were the ambitions of the person who worked for me"

- "What I enjoy the most, what makes my day most fun, is the teaching and the sharing of what I know about voice acting with a new student"

- "I would go down and see them. And I would find out what did they need to make their job better. And I took care of things for them. Simple things like - I saw their white lab coats hanging up - I said 'when's the last time somebody got you guys new lab coats?' 'It's been a while' got them all that kind of stuff. Supplies that they needed. They were like 'oh my God!' When they had problems, they knew they could call me"

\section{Employees}

- "She groomed me to become a manager. She really did. And she was a great manager. She knew how to manage people, she believed in a one-minute manager philosophy"

- "This person made a career out of having - was a strong believer that when everyone is content and having fun, the harmony creates a better work environment"

- "We each had our own mentor there. And mentors were very, very important to both of us"

- "He was behind me a thousand percent. He encouraged me to take risks. Allowed me to make mistakes. And was there to support me when I made them. And I would take a mistake to heart"

Both the young and old/male and female groups believed that Mentoring and Being Mentored was great Fun.

\section{Finding: New challenges}

Very few people want to be stuck in a rut at work, doing the same job over and over again. But at the same time, many people find change to be a burden. We discovered that, New Challenges - hard work, new jobs, and new technology - were considered fun by $89 \%$ of the participants. Of the two groups, $100 \%$ of the Management group believed that this was an essential component to having fun, while $77 \%$ of the Employees considered New Challenges as fun.

\section{Management}

- "(Employees) have to be motivated to want to figure it out - that's what it boils down to, so - "how do you make that interesting?" That's where I'm at, trying to find a way to hit hard with stuff that's very important"
- "I had fun learning how TV shows were put together. How all of that worked, how the technology worked and how there were producers and all of these people - all the behind the scenes stuff. So that was fun for me to learn it and to feel like I was a part of it"

- "It was fun for me to learn something new"

- "If we got a new client we would need to start right away writing press releases for them or pitching stories for them. So I had to do a lot of research. I had to do a lot of background checks or investigations to make sure I was knowledgeable enough to write the press release, and inform the media who then informed the public. So I really, I enjoyed that challenge of ok, let's get going, let's learn everything about this so I can get to work"

- 'I don't think you can make gains if you don't take risks. And I say that to my clients all the time. Here's a new technology I want to try for you. This looks like it's going to be amazing but I can't promise you because you're the first one that's gonna do it. And we can't make gains unless we take some risks"

\section{Employees}

- "I do best when I am able to start something new and build something that wasn't there before. That's one of my strengths. So I like the opportunity to start something new"

- "So what's fun about work is that every day is different"

- "Learning new topics, auditing techniques, or even finding different ways to like, because I do a lot of analysis work, finding a new way to speed it up"

- "You innovate and it's something that you like to do so you always find new things. And you say, 'you know what, I tried that so let me try this cause it's something that your passionate about"

- "You had two different audiences that you were producing commercials for. So there was a lot of diversity as far as your audience demographics, which made it challenging, interesting. Made it fun. Yeah, absolutely"

\section{Finding: Empowerment}

Having fun at work means being given the independence and freedom to do your job. $84 \%$ of the participants stated that this was vital to the amount of fun they had at work. $100 \%$ of the Managers believed that providing employees with Empowerment was fun, and $78 \%$ of the Employees had fun when empowered. This included the following:

\section{Management}

- "If somebody is doing their job, if they're hitting their sales goals - I'm very happy to leave them alone"

- "I think delegating allowed me to accomplish more. When I had a sales department I had more control over the message I was trying to put out there as a marketing person"

- "When we say that I managed these people, there really wasn't much managing to be done. They knew their jobs, they knew what to do, they did their jobs well - and we all got along famously. So it really was a nice experience - especially as a people manager" 


\section{Employee}

- "The freedom of that creativity. To be able to come up with different ideas, and not have somebody - for the most part have somebody say "no - do it this way, do it that way"'

- "I think it makes me feel good. It makes me feel important and it makes me feel like I um, am valued and it makes me, you know, I have a sense of pride when I do something well and it's mine and I own and I accomplish that"

- “I love my job, because it's just fun. It's no pressure. I work for myself technically. The weight of somebody over top of you, watching every move, is not there. I'm responsible for the outcome of what happens"

\section{Finding: Peer/co-worker relationships}

A great deal has been written about the significance of getting along with your co-workers. Employees who have strong bonds with the fellow employees are more productive and have better outcomes in the workplace. The finding of this study supports those claims. Our study showed that $91 \%$ of the Managers believed that Peer/Co-Worker Relationships were an important part of having fun at work, and $62 \%$ of the Employees agreed.

\section{Managers}

- "A team is a situation where you have a collaboration of people that all are working on a unified goal. When you share that and attain it with a group, that's a team effort"

- "I remember having them all over my house for dinner one night. Several people who worked for me. And I enjoyed being able to do that sort of thing - I tried to get to know on more of a personal level"

- "I'm very human, very compassionate and passionate. So I enjoy people's personalities. I appreciate people's differences. I understand people need different things, different types of attention"

- "So I get to work with all different kinds of personalities. A little bit of culture shock every once in a while, based on location. But, but I love being able to solve problems for them. And I love being able to explain things on the technology side to them in a way that they can grasp on to it, understand it and appreciate it"

\section{Employees}

- "I liked the team I worked with. I think that was a big important part of it. They knew how to have the appropriate fun in the workplace"

- "There was a decent amount of down-time, and that was always really fun because we would get to have some laid back time to hang out with each other as coworkers"

- "I like the interaction with all the different types of people that I meet"

- "I was one of those people that it charged me up to be around people that were excited and were energetic and moved quickly from this to this"

\section{Finding: Meaningful Work}

Many employees are passionate about their work because it provides purpose and meaning. The fact that this scored so low for having fun was a great surprise. This theme was expected to be much more prominent. But, as the data tells us, only $73 \%$ of the overall participants thought this was an important factor in having fun. Their responses included.

\section{Managers}

- "You know, there's a certain gratification that derives from working and it evolves. There's a gratification in meeting someone's needs, their wants"

- "So that's really kind, you know, what helped shaped me. Ok? It was the fact that I was having a lot of fun doing what I was doing and hopefully sharing that fun with the listener and making them smile. And that's what I've always thought that's what I've put there for. To entertain a little bit and make you smile a little bit"

- "When you get involved in the (Awards Ceremony Name Omitted), you're recognizing people who do extraordinary things for others without expectation of compensation or reward or recognition. And it's humbling"

- "If I said, 'you're all here at a first amendment media company to make money for the owners'; there'd be a very limited fulfillment. If you say, 'You're here working for a first amendment media company so that we can inform the public, so that they're involved, so we can address issues in our community, so that we can provide a vehicle for local businesses to be successful.' If you tell a sales person, "Your job is to go on out and sell as many ads as you can and bring money in", you got a very different kind of mentality and sense of fulfillment"

\section{Employees}

- "I told my boss once I feel like God put me here for a reason, and sometimes it's not always about me. It may be about other people. What I could do to help them"

- "I'm more about I want to make you happy, what do I have to do to make you happy?"

- "I think I felt more passion because I saw the direct affect it had on somebody. You came in and you said 'I'm looking for $\mathrm{x}, \mathrm{y}$ and $z$ ', and I could then show you this is what I can do. And then whether it is you were happy right then"

- "I love coming in here and finding a problem and fixing it. 'Oh you know what? I never looked at it like that'. That's what brings me here every day"

The data was further broken down to $91 \%$ Management and $62 \%$ Employees.

\section{Finding: Fun activities}

As Ford writes, there is very little written defining "Fun" Because of that many, people in academia believed this study should center on "engagement" Instead of "fun" [2]. They believed that having "fun" meant doing fun activities like lunches, parties and other social events. This study dispelled those thoughts as Fun Activities scored the lowest of all the findings. The bottom line is that this was the least popular fun finding by all participants. 


\section{Managers}

- "We were in the entertainment business. Some of the bosses emphasized that, so we would take people, we'd wine and dine them, make them feel comfortable as clients"

- "Where I'm at now, when we launch a new product, very often we will have a launch party. With games and prizes and trivia - you know, sometimes it's focused on whatever that product is and sometimes it's not at all. But it's just to get everybody together, gets everybody laughing, in a good mood, and you get their attention - we launch the new product and it's like shooting them out of cannon - they hit the streets running"

- "Just get everybody together at lunchtime. Leave everything aside and sit down and eat a bowl of soup. So that was one thing that we did. Another thing that we did was we had a meeting every Tuesday. And I would start it with a game. So we'd have to go around the table and everybody had to name two things that happened to them"

\section{Employees}

- "They literally shut down the entire zoo, and they also brought in food. You had different stations of all different types of food and to me that's just like - hey we care, obviously this is costing us - I mean to close down a zoo for the day? I imagine there's a large cost to it but we care enough about you to do all this stuff"

- "So like, there were treadmill desks in different, like these little offices. So when you got tired of sitting, you could go and walk on the treadmill and do your work at the same time. The desks would rise to standing desks"

- "I mean the building was so funky and so cool. They had a huge cafeteria; it was more like a restaurant. Like a cool restaurant though. We had chefs on staff and they had a fitness center and they had closets with clothes in it"

\section{Discussion}

Several patterns emerged from the qualitative study. In particular, we discovered six specific categories contributed to fun in the workplace: Mentoring/Being Mentored (91\%); New Challenges (87\%); Empowerment (84\%); Peer/Co-Worker Relationships (82\%); Meaningful Work (73\%); and lastly, Fun Activities (70\%). Much of the research that supports these patterns comes from such esteemed authors as Porter and Lawler [16], Herzberg [15], Gagne [17], Boyatzis et al. [5] and Vroom [18], who cites improvements in productivity, job satisfaction and overall well-being of the company as the end result. Their discoveries provide a supportive framework for this study and are presented below.

\section{Mentoring}

What is often studied about Mentoring is the protege outcome. Very little is dedicated to the effects of mentoring for the mentor. Stenfors-Hayes' study focused on this notion. The study discovered that the second-most popular reason why mentors liked mentoring was it "related to being fun" [19]. this was behind rewarding terms such as "stimulating" Or "developing", and was overwhelmingly popular amongst all her participants [19]. She wrote "(Mentors) appreciated feeling important and needed" [19]. Cheryl Wright notes that mentors express the great pride they realize in their protege's accomplishments [20]. She also writes that the mentors feel a sense of immortality as if they are passing on their knowledge, and creating a lasting contribution to the workplace [20]. Ragins and Scandura agree with Wright and found that mentors feel a great sense of satisfaction and fulfillment from being a mentor, especially when the protege is a young adult [21]. Seligman and Achor also wrote that fulfilling and meaningful work leads to happy employees [22,23]. The belief is that managers who mentor will increase their own personal happiness, which will affect their employees' job satisfaction [6].

This discovery was further supported by Chi et al. [6], who found that "the relationship between leader's positive moods and team performance" directly enhanced employee performance and led to more cohesive team structures [6]. They further discovered that this positive mood affected group "tone" and the amount of team socialization, productivity, and job satisfaction [6]. Thompson wrote that a leader who is caring and involved is the "the critical ingredient" in successful organizations. They found that the manager's ability to communicate was instrumental in the success of both the employee and the company [24].

Boyatzis et al. wrote that leaders "use their emotional intelligence to build shared hope, compassion and mindfulness" in their relationships with employees [5]. The authors propose a model of "coaching" In which the "coach" (Manager) establishes a trusting relationship with the "coachee" (employee) and freely discuss their hopes and dreams (Appendix 1). This evokes a sense of caring and compassion, and creates an organization open to new ideas and possibilities [5].

\section{New Challenges}

Many of the participants of this qualitative study noted how New Challenges were fulfilling, engaging and fun. While a great deal has been written about the relationship of engagement to employee effort [25-27], the notion of hard, challenging work as "fun" has not received much attention. Schaufeli writes that "Challenging jobs produce engagement" [28], which creates a sense of fulfillment, which makes an employee have fun.

Furthermore, Individuals who are self-determined are driven by two distinct qualities: Extrinsic Motivators and Intrinsic Motivators. These are explained by Gagne and Deci's article: Self-Determination Theory (SDT) and Work Motivation [17], which builds on the work of Porter and Lawler [16] and Vroom [18]. The SDT classifies Intrinsic Motivation as an example of Autonomous Motivation, which involves "acting with a sense of volition and having the experience of choice" $[16,17]$. The authors discovered that people engage in an activity "because they find it interesting ('I work because it is fun!')" [17] conversely, people who are controlled feel pressured by deadlines, surveillance and evaluations [17].

Gagne later writes with Meyer that self-determination "has been demonstrated to lead to higher levels of performance, persistence, initiative and creativity" [26], which in turn creates employees who are more engaged and satisfied with their jobs [26].

\section{Empowerment}

Wilkinson defines empowerment as a "form of employee involvement" that gained considerable attention in the 1980s for its focus on task-based involvement [29]. The author wrote that "it is employers who decide whether and how to empower employees" [29], which lead to an "enhanced employee contribution to the organization" [29]. Wilkinson cites Elton Mayo who wrote that "involving workers had strong business as well as moral benefits" [30]. Wilkinson also drew upon author Tom Peters, who wrote the best-selling book In Search 
of Excellence in 1982. The theory is that "managers could unleash the talents of individuals by dismantling organizational bureaucracy" [29].

The Enthusiastic Employee: How Companies Profit by Giving Workers What They Want [31] applies to several different areas of this paper, but in Chapter Five they write "giving trained workers latitude in the way they do their jobs has a major positive impact on their performance" [31]. The notion is that employees know how to do their jobs most efficiently and effectively, and take ownership of their work. The authors discovered that employees who are micro-managed feel as though they cannot be trusted to carry out their duties, and are less inclined to perform productively [31].

\section{Peer/co-worker relationships}

"The integration of fun and work isn't about what you do; it's about whom you're being when you're doing your work" [32].

In her work Determinants of Employee Engagement and Their Impact on Employee Performance, author Anitha cites that team and co-worker relationships are vital to a company's "interpersonal harmony" [33]. Khan also found that "supportive and trusting interpersonal relationships, as well as a supportive team, promote employee engagement" Sirotta wrote that this "social capital" is significant as well. He discovered that "cooperative relationships are critical for effective performance and, therefore, for a sense of achievement in one's work" He wrote that conflict among employees is "needlessly costly"

According to the Gallup Management Journal study, supervisors play a critical role in worker well-being and engagement. The survey considers how employee perceptions of happiness and well-being affect job performance. Happy and engaged employees are better equipped to handle stress and change, are much more likely to have a positive relationship with their manager, feel more valued by their employer and are more satisfied with their lives. People with higher levels of engagement appear to substantially enjoy more positive interactions with co-workers than do their less-engaged counterparts. The study suggests that organizations can boost firm productivity if they recognize these issues and help employees improve their well-being [25].

\section{Meaningful/fulfilling work}

In his book The Happiness Advantage, Achor [23] writes that happy people are more likely to succeed than unhappy people. Achor [23] calls upon the work of noted author Martin Seligman, who he regards as a "pioneer in positive psychology", to validate his findings $[22,34]$. Achor writes that Seligman categorizes happiness into three measurable components: pleasure, engagement and meaning. $\mathrm{He}$ writes that people who are happy have a psychological advantage [23].

Boyatzis' research is also related to this theory [35]. He discovered that "positive emotions have been shown to result in more altruistic, helpful, cooperative and conciliatory behavior" that creates a feedback loop between management and employees [35]. He further discovered that the relationship between an employee's job satisfaction, organizational commitment, and effort is directly related to the manager's ability to generate a Positive Emotional Attractor (PEA) [35].

Herzberg wrote that Job Enrichment is not a "one-time proposition, but a continuous management function" [15]. He also wrote that "not all jobs can be enriched" [15]. Many companies don't have the time, staff, resources or money to implement such a wideranging, all-encompassing initiative. Therefore, all the work done to identify methods to increase job satisfaction could possibly end up underutilized - or not utilized at all.

Further research by Shuck and Rose found that leaders who "develop high levels of employee engagement within their organizations enjoy increased levels of competitive advantage" [36]. Their research explored the strategies practitioners can use to "cultivate positive conditions for employee engagement" [36]. Their study discovered that employees "give to the organization what they perceive they receive in return", and that employers "must be adept at showing that work is purposeful and meaningful" [36] in order to create a more engaged employee who is more productive and satisfied with their job.

Sirota et al. wrote that empowering employees demonstrates trust and goodwill "that allows people to go beyond what is required" [31] and builds a Win-Win partnership that builds their confidence and self-esteem. It is a give-and-take arrangement, in which employees not only share in the firm's successes, but also in their financial gains. This Partnership Theory is the "surest path to a high-performance organization”

Yerkes sums it up best: "People are demanding more from their jobs than merely a paycheck. They expect to enjoy what they do and they will search and move until they are satisfied with their work experience" [32].

\section{Fun activities}

Our findings indicate that Fun Activities are the least important factor in creating a fun and engaging workplace. Even so, it was still an important ingredient in the overall success.

Ford explains "introducing quirky workplace activities, group lunches, or after-hours outings, workplace morale and productivity improve" [2]. Some of the ways to promote fun activities in the workplace include "celebrations, entertainment, playing games, having friendly competitions, social events and humor" [2].

\section{Analysis}

Several important findings emerged from the research: Mentoring is fun; Hard Work is fun and Fun Activities are not as important as we were led to believe in having fun at work. Many of the participants said that having fun at work gave them the ability to grow as individuals, become more creative, more responsible and more independent. Mentoring was the most surprising discovery, especially the fact that it scored the highest among the six findings. More importantly, we discovered that there is very little literature written about the "Mentor" side of the equation - the benefit to the Mentor. We found that the breadth of research centers on the effect mentoring has on the protege - very little is written about the effect it has on the Mentor.

Many of our Employees considered Mentors as Role Models who provided them with structure and balance, great training, showed a high degree of selflessness, and led by setting a good example. The Managers spoke about the joy of training the protege, about the loyalty the protege exhibited, and the great pride that results from seeing the protege grow. One Mentor summed it up this way: "I can't tell you how many people point to me and say, "You changed my life"

We were not surprised to discover that people viewed the New Challenges category with such high regard. This category included such topics as hard work, risk-taking, undertaking new projects, learning new processes, identifying and implementing new policies and procedures, and career changes. Schaufeli and Salavona break down "engagement" 
into three distinct categories: Vigor, Dedication and Absorption [28]. They write that Vigor "refers to high levels of energy and resilience, the willingness to invest effort in one's job, not being easily fatigued and persistence in the face of difficulties"; Dedication "refers to a strong involvement in one's work, accompanied by feelings of enthusiasm and significance, and by a sense of pride and inspiration"; and Absorption, which refers to "a pleasant state of total immersion in one's work which is characterized by time passing quickly and being unable to detaching oneself from the job" [28]. Comerford writes that given the choice, many employees would prefer more effortful work than effortless work [9]. Lockwood regards the opportunity to perform well at challenging work among her top ten ways to measure employee engagement. She writes that employers should "provide opportunities and challenges" for employees so that they become further engaged with the work [25]. One of our respondents was so engrossed with his work, he lamented: "I hardly ever go out. My friends were going to have interventions because I wasn't coming out. They were pissed off at me. And it's like - I don't miss it! Now there's just not enough time to do the stuff that I want to do".

In summary, we believe that incorporating a mentoring program into a company will provide numerous long-term benefits. We also believe that this program should be organic and nature, not structured. Managers should be encouraged to mentor, but they should be the ones to decide whom they will mentor. We believe that this initiative will directly affect all other factors and create a more enjoyable workplace.

\section{Limitations}

One of the key reasons why the advertising, marketing and sales industry was selected for this study was their naturally creative, independent and innovative approach to conducting business. While this brought great insight into our findings, we realize that other industries - such as manufacturing - may not be influenced by this approach. We were also limited to the Greater Albany, NY/Capital Region market. While ranked $52^{\text {nd }}$ in market size, future research should include other/larger markets.

\section{Future Research}

This study provided several key findings, especially the significant role mentoring plays in a manager's fun at work. We also discovered five other factors that influence senior-level managers to have fun at work.

What needs to be done next is a further study on what is not fun in the workplace. Our findings indicated several factors, but further work needs to be developed in order to create a meaningful body of data. Furthermore, consideration needs to be given to a uniform method to assess fun and provide clear-cut definitions to what can be considered as fun and what should not be considered as fun.

Lastly, we would like to examine the different types of Mentorship programs: Structured or Organic. We believe that an organic mentorship program - one that develops informally and mutually has more impact on the amount of fun a manager has than a more structured/formal mentorship.

\section{References}

1. Clark RM (2009) Are we having fun yet? Creating a motivating work environment. Ind Commer Train 41: 43-46.

2. Ford RC, Mclaughlin FS, Newstrom JW (2003) Questions and answers about fun at work. HRP 26: 18-33.

3. Kinjerski V, Skrypnek BJ (2006) Creating organizational conditions that foster employee spirit at work. Leadership Org Dev J 27: 280-295.
4. Bedeian AG, Armenakis AA (1998) The cesspool syndrome: How dreck floats to the top of declining organizations. Acad Manag Exe 12: 58-63.

5. Boyatzis RE, Smith ML, Beveridge AJ (2012) Coaching with compassion Inspiring health, well-being, and development in organizations. J Appl Behav Sci 49: 153-178.

6. Chi NW, Chung YY, Tsai WC (2011) How Do Happy Leaders Enhance Team Success? The Mediating Roles of Transformational Leadership, Group Affective Tone, and Team Processes. J Appl Soc Psychol 41: 1421-1454.

7. Moberg DJ (2000) Role Models and Moral Exemplars: How Do Employees Acquire Virtues by Observing Others? Bus Ethics Q 10: 675-696.

8. Bolton S, Houlihan M, Baptiste NR (2009) Fun and well-being: insights from senior managers in a local authority. Employee Relations 31: 600-612.

9. Comerford DA, Ubel PA (2013) Effort Aversion: Job choice and compensation decisions overweight effort. J Econ Behav Organ 92: 152-162.

10. Head S (2003) The new ruthless economy: work \& power in the digital age Oxford University Press New York.

11. Bates S (2004) Getting Engaged. HR Magazine 49: 44-51.

12. Saks AM, Gruman JA (2014) What Do We Really Know About Employee Engagement? Human Resource Development Quarterly 25: 155-182.

13. Gallagher WE, Einhorn HJ (1976) Motivation theory and job design. J Bus 49: 358-373.

14. Lutchman C, Maharaj R, Ghanem W (2012) Safety Management: A Comprehensive Approach to Developing a Sustainable System. CRC Press.

15. Herzberg F (1968) One more time: How do you motivate employees? Harv Bus Rev 46: 53-62.

16. Porter LW, Lawler EE (1968) Managerial attitudes and performance. AGRIS

17. Gagne M, Deci EL (2005) Self-determination theory and work motivation. $J$ Organ Behav 26: 331-362.

18. Vroom VH (1964) Work and motivation. Oxford, England: Wiley.

19. Stenfors-Hayes T, Kalen S, Hult H, Dahlgren LO, Hindbeck H, et al, (2010) Being a mentor for undergraduate medical students enhances personal and professional development. Medical teacher 32: 148-153.

20. Wright CA, Wright SD (1987) The role of mentors in the career development of young professionals. Fam Relat 36: 204-208.

21. Ragins BR, Scandura TA (1999) Burden or blessing? Expected costs and benefits of being a mentor. J Organ Behav 20: 493-509.

22. Seligman MEP (2002) Authentic happiness: Using the new positive psychology to realize your potential for lasting fulfillment. Free Press.

23. Achor S (2011) The happiness advantage: The seven principles of positive psychology that fuel success and performance at work. Random House.

24. Thompson JW (1996) Employee Attitudes, Organizational Performance, and Qualitative Factors Underlying Success. J Bus Psychol 11: 171-196.

25. Lockwood NR (2007) Leveraging employee engagement for competitive advantage. Society for Human Resource Management Research Quarterly 1: $1-12$.

26. Meyer JP, Gagne M (2008) Employee engagement from a self-determination theory perspective. Ind Organ Psychol 1: 60-62.

27. Rodriguez-Munoz A, Sanz-Vergel AI, Demerouti E, Bakker AB (2014) Engaged at work and happy at home: A spillover-Crossover model. J Happiness Stud 15: $271-283$.

28. Schaufeli W, Salanova M (2007) Work engagement. Managing social and ethical issues in organizations, pp: 135-177.

29. Wilkinson A (1998) Empowerment: Theory and Practice. Pers R 27: 40-56.

30. Mayo E (1945) The social problems of an industrial civilization. Int J Sociol.

31. Sirota D, Mischkind LA, Meltzer MI (2006) The enthusiastic employee: How companies profit by giving workers what they want. Pearson Education.

32. Hemsath D, Yerkes L (1997) 301 Ways to Have Fun At Work. Berrett-Koehler Publishers. 
Citation: Scardillo A (2018) "Are We Having Fun Yet?" What Factors Influence Managers to Have Fun at Work?. J Entrepren Organiz Manag 7: 230. doi: 10.4172/2169-026X.1000230

Page 8 of 8

33. Anitha J (2014) Determinants of employee engagement and their impact on employee performance. Int J Prod Perform Manag 63: 308-323.

34. Seligman M (2010) Positive Psychology \& Positive Interventions.

35. Boyatzis RE (2013) When pulling to the negative emotional attractor is too much or not enough to inspire and sustain outstanding leadership. The Fulfilling Workplace: The Organization's Role in Achieving Individual and Organizational Health, pp: 139-150.

36. Shuck B, Rose K (2013) Reframing Employee Engagement within the Context of Meaning and Purpose: Implications for HRD. Adv Dev Hum Resour 15: 341-355. 